\title{
Efforts to Improve Learning Activeness of Grade 5 Students Through the Google Meet Application
}

\section{Eka Septi Haryani}

SD Negeri Banjaranyar

ekaseptiharyani310812@gmail.com

\section{Article History}

accepted 01/11/2020

approved 08/11/2020

published 15/11/2020

\begin{abstract}
The background of this research is that online learning is not optimal because it only uses the Whatshapp group and there are still many students who do not submit assignments. The purpose of this study is to describe the use of google meet in order to increase student learning activity in class V SD Negeri Banjaranyar. The research conducted was Classroom Action Research which consisted of planning, implementing, observing and reflecting. In the first cycle the percentage of students was 5\% less active, $40 \%$ active enough and $55 \%$ active students. Whereas in cycle II the percentage of students was quite active $25 \%$ and only $75 \%$ active students. The percentage of student activeness in cycle III is 95\% active students and $5 \%$ of students are quite active. This result shows that the use of the google meet application can increase student activity in grade 5 SD Negeri Banjaranyar.
\end{abstract}

Keywords: active learning, Google Meet

\begin{abstract}
Abstrak
Latar belakang penelitian ini adalah pembelajaran secara daring tidak maksimal karena hanya memanfaatkan Whatshapp group dan masih banyaknya siswa yang tidak mengumpulkan tugas. Tujuan dari penelitian ini yakni mendeskripsikan penggunaan google meet agar dapat meningkatkan keaktifan belajar siswa di kelas V SD Negeri Banjaranyar. Penelitian yang dilakukan adalah Penelitian Tindakan Kelas yang terdiri dari perencanaan, pelaksanaan, observasi dan refleksi. Pada siklus I persentase siswa kurang aktif $5 \%$, cukup aktif $40 \%$ dan siswa yang aktif $55 \%$. Sedangkan pada siklus II persentase siswa cukup aktif $25 \%$ dan siswa yang aktif hanya $75 \%$. Pesrsentase keaktifan siswa pada siklus III adalah siswa aktif $95 \%$ dan $5 \%$ siswa cukup aktif.Hasil ini menunjukan bahwa penggunaan aplikasi google meet dapat meningkatkan keaktifan siswa di kelas 5 SD Negeri Banjaranyar.
\end{abstract}

Kata kunci: Keaktifan Belajar, Google Meet,

Social, Humanities, and Education Studies (SHEs): Conference Series https://jurnal.uns.ac.id/shes 


\section{PENDAHULUAN}

Saat ini kemajuan teknologi sudah tidak dapat terhidar lagi, hampir setiap ranah dalam kehidupan tidak luput dari pengaruh dari kemajuan teknologi. Contoh simpelnya adalah penggunaan gadget yang tidak dapat lepas pada kegiatan sehari-hari manusia. Gadget saat ini digunakan bukan hanya karena dibutuhkan namun karena sebuah kebutuhan. Pada masa pandemi ini, semua aktivitas dipindahkan ke rumah, termasuk juga sekolah. Sejak diberlakukannya Surat Edaran Nomor 4 Tahun 2020 Tentang Pelaksanaan Kebijakan Pada Masa Pandemi Belajar dari Rumah melalui pembelajaran daring/jarak jauh dilaksanakan untuk memberikan pengalaman belajar yang bermakna bagi peserta didik, tanpa terbebani tuntutan menuntaskan seluruh capaian kurikulum untuk kenaikan kelas maupun kelulusan. Dengan adanya hal tersebut, maka otomatis seluruh aktivitas, baik kantor maupun sekolah, dilakukan secara online atau daring (dalam jaringan). Perubahan yang berlangsung tiba-tiba tersebut memaksa kita semua untuk beradaptasi sesegera mungkin. Jika tidak, maka kita ketinggalan seluruh aktivitas yang tengah berjalan. Bekerja, belajar, hingga ujian, seluruh dilakukan dengan bantuan jaringan internet.

Pada masa sekarang baik guru ataupun peserta didik menggunakan gadget untuk menyampaikan materi pembelajaran secara daring(dalam jaringan). Kegiatan belajarmengajar saat ini digantikan dengan metode pembelajaran daring. Banyak aplikasi video konferensi yang bisa digunakan, salah satunya Google Meet yang merupakan fitur premium dari software video conferencing Google. Google Meet sangat berperan penting dalam kegiatan belajar. Apalagi penggunaannya mudah, tidak perlu di download sangat membantu mengurangi ruang penyimpanan pada smartphone. Dengan adanya aplikasi Google Meet ini diharapakan mempermudah siswa untuk belajar sehingga dapat meningkatkan keaktifan peserta didik serta hasil belajarnya pun tetap meningkat. Pengertian google meet adalah produk dari Google yang merupakan layanan komunikasi video yang dikembangkan oleh Google. Penciptaan dan pembaruan Google Meet yang jauh lebih menarik dan menawarkan fitur- fitur terbaik dibandingkan dari pendahulunya Google Hangouts klasik, inilah keunggulan yang ditawarkan Google Meet dalam antara lain (1)Membantu para pekerja dan karyawan untuk tetap melakukan rapat dimana saja mereka berada dengan menggunakan video call, (2) Interface atau antarmuka yang unik dan fungsional dengan ukuran ringan serta cepat, mengedepankan pengelolaan yang efisien, mudah guna (user friendly) yang dapat diikuti semua pesertanya, (3) Pengguna dapat mengundang peserta rapat dan berbagi fitur.

Berdasarkan hasil penelitian pembelajaran daring yang telah dilakukan, pada kenyataannya belumlah sesuai dengan harapan, Peneliti merasakan adanya permasalahan yang berhubungan dengan keaktifan belajar peserta diidk dalam kegiatan pembelajaran daring sangat kurang. Peserta didik kurang aktif dalam pembelajaran secara daring, masih banyak peserta didik yang tidak mengumpulkan tugas daring yang diberikan oleh guru. Penyebab adanya permasalahan tersebut yaitu siswa mengalami kesulitan dalam belajar, karena hanya memanfaatkan aplikasi Whatssapp group (WAG) dan media pembelajaran yang kurang menarik. Berdasarkan hal tersebut, peneliti akan melakukan penelitian tindakan kelas untuk meningkatkan keaktifan belajar peserta didik tema 4 sehat itu penting sub tema 3 cara memelihara kesehatan organ peredaran darah manusia melalui penggunaan aplikasi Google Meet di kelas V SD Negeri Banjaranyar Kecamatan Pekuncen.

Menurut Hopkins (1993), penelitian tindakan kelas diawali dengan perencanaan tindakan (Planning), penerapan tindakan (action), mengobservasi dan mengevaluasi proses dan hasil tindakan (Observation and evaluation). Sedangkan menurut Arikunto, dkk (2009:16) terdapat 4 tahapan yang lazim dilalui dalam model penelitian Tindakan kelas yaitu perencanaan, pelaksanaan, pengamatan dan refleksi. 
Tujuan dari penelitian ini adalah meningkatkan keaktifan peserta didik dalam pembelajaran. menurut Oemar Hamalik (2009:23-23) membagi jenis keaktifan siswa dalam belajar ada 8 aktivitas yaitu mendengar, melihat, mencium, merasa, meraba, mengolah ide, menyatakan ide dan melakukan latihan. Menurut Dimyati \& Mudjiono (2006: 45) indicator keaktifan mencakup antaranya: 1) siswa mau mencatat atau sekedar mendengarkan penjelasan guru, 2) siswa memperhatikan hal-hal yang dijekaskan oleh guru tentang materi pelajaran, 3) siswa mencatat tugas yang diberikan dan mengerjakan tugas rumah, 4) siswa mau berdiskusi dalam kelompok untuk memecahkan masalah yang berkaitan dengan pelajaran, 5) siswa mampu melibatkan diri dalam proses Tanya jawab dalam kelas, 6) siswa mau terlibat dalam menyimpulkan pembalajaran bersama guru dan teman siswa lainnya.

Pembelajaran aktif merupakan suatu bentuk pembelajaran yang lebih banyak melibatkan aktivitas siswa dalam mengakses berbagai informasi dan pengetahuan untuk dibahas dan dikaji dalam proses pembelajaran di kelas, sehingga mereka mendapatkan berbagai pengalaman yang dapat meningkatkan pemahaman dan kompetensinya. Yulisetiani, dkk (2018) mengungkapkan bahwa dalam mewujudkan pembelajaran aktif di kelas, guru perlu menyajikan bahan ajar otentik dan kontekstual. Bahan ajar yang dekat dengan siswa akan membuat siswa lebih mudah memahami dan aktif di dalam kelas selama proses pembelajaran.

Lebih dari itu, pembelajaran aktif memungkinkan siswa mengembangkan kemampuan berfikir tingkat tinggi, seperti menganalisis dan mensintesis, serta melakukan penilaian terhadap berbagai peristiwa belajar dan menerapkan kehidupan sehari-hari (Rusman, 2011). Sementara menurut Paul B. Diedrich (Sadirman, 2006 : 101) menjelaskan bahwa aktivitas belajar siswa antara lain, yaitu:Visual activities, Oral activities, Listening activities, Writing activities, Motor activities.

Berdasarkan latar belakang dan identifikasi permasalahan diatas, maka masalah penelitian dapat dirumuskan sebagai berikut bagaimana cara mendeskripsikan penggunaan google meet agar dapat meningkatkan keaktifan belajar siswa Tema Sehat itu penting Sub Tema Cara Memelihara Kesehatan Organ Peredaran darah manusia di kelas $V$ semester I SD Negeri Banjaranyar pada masa pandemi

\section{METODE}

Penelitian ini merupakan Penelitian Tindakan Kelas ( PTK) yang berlangsung dalam tiga siklus, setiap siklus terdiri atas 1) perencanaan (planning), 2) pelaksanaan tindakan (action), 3) pengamatan (observation) dan 4) refleksi (reflection). Subjek penelitian ini adalah peserta didik kelas V SD Negeri Banjaranyar Kecamatan Pekuncen sebanyak 20 peserta didik. Analisis penelitian ini adalah analisis deskriptif dimana dalam penelitian ini penyajian hasil berupa data, peneliti juga menentukan bagaimana cara pengolahan hasil penelitian yakni dengan membuat analisis keaktifan peserta didik dalam pembelajaran menggunakan aplikasi google meet. Siklus I dilaksanakan pada tanggal 22 Oktober 2020. Siklus II dilaksanakan pada tanggal 2 November 2020 dan siklus III dilaksanakan pada tanggal 14 November 2020. Teknik pengumpulan data yang dilakukan dengan observasi dan tes. Observasi meliputi observasi keterlaksanaan google meet pembelajaran dan observasi keaktifan peserta didik. 


\section{HASIL DAN PEMBAHASAN}

Penelitian ini dilaksanakan pada bulan Oktober 2020 s.d November 2020 Penelitian dilaksanakan 3 siklus. Data penelitian diperoleh dari 3 siklus yang terdiri dari empat tahapan yaitu perencanaan, tindakan, pengamatan, dan refleksi. Hasil penelitian menunjukkan peningkatan keaktifan belajar peserta didik kelas V SD Negeri Banjaranyar pada materi tema 4 (sehat itu penting) sub tema 3 (cara memelihara kesehatan organ peredaran darah manusia) dapat terlihat pada tabel berikut ini:

\section{Tabel 1. Peningkatan Keaktifan Belajar}

\begin{tabular}{ccccccc}
\hline & \multicolumn{2}{c}{ Siklus I } & \multicolumn{2}{c}{ Siklus II } & \multicolumn{2}{c}{ Siklus III } \\
Kriteria & $f$ & $\%$ & $f$ & $\%$ & $f$ & $\%$ \\
\hline Kurang Aktif & 2 & $10 \%$ & 1 & $5 \%$ & 1 & $5 \%$ \\
Cukup Aktif & 8 & $40 \%$ & 5 & $25 \%$ & 1 & $5 \%$ \\
Aktif & 10 & $50 \%$ & 14 & $70 \%$ & 18 & $90 \%$ \\
\hline
\end{tabular}

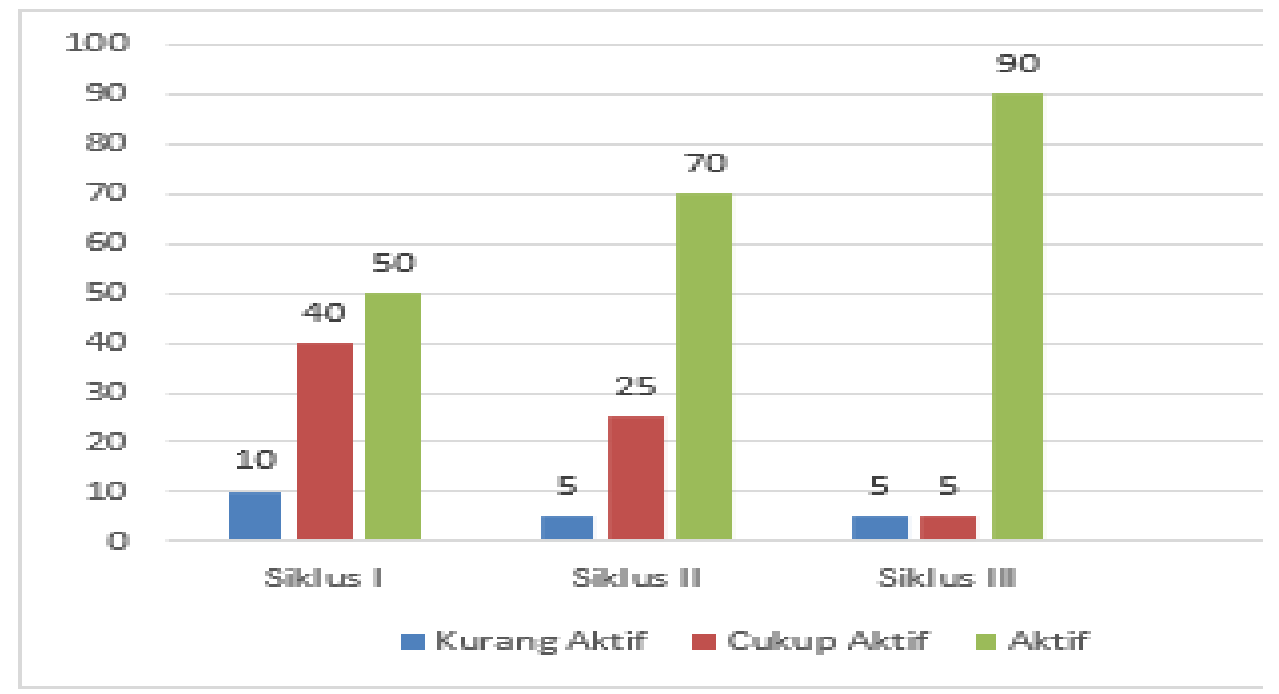

Gambar 1. Peningkatan Keaktifan Belajar

Dari diagram diatas menunjukkan peningkatan keaktifan belajar peserta diidk di kelas V SD Negeri Banjaranyar pada materi tema 4 (Sehat itu penting) Sub Tema 3 dengan menggunakan aplikasi googel meet dalam proses pembelajaran secara daring. Teknik pengumpulan data hasil belajar peserta didik diterapkan pada setiap pertemuan setelah dilakukan kegiatan pembelajaran dengan menggunalan lembar observasi. Pada siklus I keaktifan belajar peserta didik hanya 50\%. Setelah dilakukan tindakan persentase keaktifan belajar pada siklus II meningkat menjadi $70 \%$. Pada siklus III 
terjadi peningkatan kembali yang mencapai $90 \%$, sehingga pelaksanaan tindakan dapat dihentikan. Berdasarkan tabel keaktifan belajar peserta didik terhadap penggunaan aplikasi google meet dapat dilihat bahwasanya peserta didik sangat tertarik untuk belajar dan aktif dalam kegiatan pembelajarannya.

\section{SIMPULAN}

Penggunaan aplikasi google meet pada pembelajaran dapat meningkatkan keaktifan peserta didik kelas V SD Ngeri Banjaranyar. Peningkatan yang terjadi dikarenakan adanya kesan pembelajaran yang mendalam dari peserta didik tehadap materi yang diajarkan melalui aplikasi google meet. Peserta didik menjadi lebih aktif dalam kegiatan pembelajaran dan selalu tepat waktu dalam pengumpulan tugas yang diberikan oleh guru. Berdasarkan penelitian yang telah dilaksanakan, guru hendaknya dapat menguasai program IT untuk kegiatan pembelajaran, penggunaan apliksi ini sangat cocok digunakan dalam keadaan pandemi seperti ini, apalagi dalam kondisi belajar dari rumah. Peserta didik akan tetap aktif dalam pembelajaran dan guru bisa memantau langsung proses pembelajaran yang sedang dilkukan.

\section{DAFTAR PUSTAKA}

Arikunto, Suharsimi, dkk. 2009. Penelitian Tindakan Kelas. Jakarta: Sinar Dimyati dan Mudjiono. 2006. Belajar dan Pembelajaran. Jakarta: PT Rineke Cipta Hopkins. (1993). Desain Penelitian Tindakan Kelas (Model Ebbut). Yogyakarta: Pustaka Belajar.

Hamalik, Oemar. 2009. Kurikulum dan Pembelajaran. Jakarta. Bumi Aksara

Rusman. (2011). Model-Model Pembelajaran Mengembangkan Profesionalisme Guru. Jakarta: PT. Rajagrafindo Persada.

A.M, Sardiman. 2006. Interaksi dan Motivasi Belajar-Mengajar. Jakarta : PT. Raja Grafindo Persada

SE Mendikbud: Pelaksanaan Kebijakan Pendidikan dalam Masa Darurat Penyebaran Covid-19. (2020). https://ww.kemdikbud.go.id

Yulisetiani, S., dkk. (2018). Prophetic Ethics of Banyumas Women in Kubah Novels by Ahmad Tohari As A Teaching Materials and Media For Strengthening Character. Advances in Social Science, Education and Humanities Research, 184-187.

https://idcloudhost.com/mengenal-google-meet-fitur-keunggulan-dan-cara-

menggunakannya/ 